\title{
Efektivitas Media Edukasi Audio-visual dan Booklet terhadap Pengetahuan Premenopause, Efikasi Diri dan Stres pada Wanita Premenopause di Kota Bandung
}

\section{The Effectiveness of Audio-visual and Booklet Educational Media on Premeno- pausal Knowledge, Self-Efficacy and Stress in Premenopausal Women in Bandung City}

\author{
Ridwan Setiawan ${ }^{1}$, Iryanti $^{1 *}$, Muryati $^{2}$ \\ ${ }^{1}$ Jurusan Promosi Kesehatan, Politeknik Kesehatan Kementerian Kesehatan Republik Indonesia, \\ Bandung 40171.
}

${ }^{2}$ Jurusan Keperawatan, Politeknik Kesehatan Kementerian Kesehatan Republik Indonesia, Bandung 40171.

\author{
*Korespondensi penulis: \\ iryanti511@gmail.com
}

\begin{tabular}{ll}
\hline Diterima (Recieved) & $: 29$ April 2020 \\
Direvisi (Revised) & $: 27$ Mei 2020 \\
Diterima untuk diterbitkan (Accepted) & $: 27$ Juni 2020
\end{tabular}

\begin{abstract}
ABSTRAK
Latar Belakang. Jumlah wanita menopause di Indonesia saat ini sebanyak 7,4\% dari total populasi, dan tahun 2020 jumlahnya diperkirakan mencapai 11,54\%. Menopause diawali dengan premenopause, dimana pada masa ini terjadi penurunan hormon estrogen yang memunculkan sindrom premenopause yang dapat mengakibatkan stres pada wanita.

Tujuan. Penelitian ini dilakukan untuk mengetahui efektivitas media edukasi audio-visual dan booklet terhadap pengetahuan premenopause, efikasi diri dan tingkat stres pada wanita premenopause di Kota Bandung.

Metode. Jenis penelitian adalah quasi experiment dengan pre-post test with control group design. Jumlah partisipan sebanyak 76 orang, terdiri dari 38 orang kelompok intervensi dan 38 orang kontrol.

Hasil. Penelitian ini menemukan bahwa pada kelompok intervensi rerata pengetahuan 6,09 poin lebih tinggi, rerata efikasi diri 3,05 poin lebih tinggi, dan rerata stres terjadi penurunan 1,23 poin dibandingkan dengan kelompok kontrol. Penggunaan audio-visual dan booklet sebagai media edukasi berhubungan dengan meningkatnya pengetahuan mengenai premenopause dan efikasi diri, serta efektif menurunkan stres wanita premenopause di Kota Bandung ( $\mathrm{p}<0,05)$.

Kesimpulan. Pemberian edukasi menggunakan media audio-visual dan booklet efektif dapat meningkatkan pengetahuan wanita premenopause tentang premenopause.
\end{abstract}

Kata Kunci: audio-visual, booklet, efikasi diri, premenopause.

\begin{abstract}
Background. The number of menopausal women in Indonesia is currently $7.4 \%$ of the total population, and its number is estimated up to $11.54 \%$ in 2020. The menopausal period is preceded by premenopausal phase in which the estrogen hormone is decreased, causing premenopausal syndromes that may lead to stres in women.

Objective. This study was to assses the effectiveness of audio-visuals and booklets as educational medium on the knowledge about premenopause, self-efficacy and stres level of premenopausal women in Bandung.

Method. Design of the study was quasi experiment using pre-post test with control group design. There were 76 participants, consisting of 38 participants in intervention group and 38 participants in control group.

Results. This study found that the scores of knowledge was higher 6.09 points, self-efficacy was higher 3.05 point, and stres level was decrased by 1.23 point in the intervention group than in the control group. The use of audio-visual and booklet as educational medium was associated with increasing knowledge and selfefficacy as well as effective in reducing stres level in premenopausal women in Bandung City.

Conclusion. Providing education through audiovisuals and booklets was effective in increasing knowledge of premenopausal women concerning premenopause.
\end{abstract}

Keywords: audio-visual, booklet, self-efficacy, premenopause. 


\section{LATAR BELAKANG}

Indonesia saat ini memiliki $7,4 \%$ wanita menopause dari total populasi dan tahun 2020 diperkirakan mencapai $11,54 \%$ dengan usia rata-rata menopause 49 tahun. ${ }^{1}$ Peningkatan populasi wanita menopause pada umumnya disertai berbagai tingkat dan jenis masalah yang kompleks sehingga berdampak pada peningkatan masalah kesehatan yang dialami wanita menopause tersebut. Masa menopause merupakan keadaan di mana seorang wanita tidak lagi mengalami menstruasi. ${ }^{2}$ Pada masa ini dapat diawali dengan masa premenopause, dimana pada masa ini terjadi penurunan hormon estrogen yang menyebabkan masalah sindrom premenopause. Premenopause adalah suatu kondisi fisiologis pada wanita saat memasuki masa penuaan yang dapat ditandai turunnya kadar hormon estrogen ovarium pada wanita yang berperan dalam reproduksi seksualitas dan dapat mengganggu aktifitas wanita. Masa premenopause biasanya terjadi di usia 40-an. ${ }^{3}$

Hasil Study of Women's Health Across the Nation di Amerika Serikat menunjukkan bahwa masa menopause berhubungan dengan tekanan psikologi, dimana sebanyak $28,9 \%$ mengalami stres diawal premenopause, $20,9 \%$ pada tahap premenopause, dan sebanyak $22 \%$ mengalami tahap post menopause. ${ }^{4}$ Penelitian Anaqotul dan Suprihatiningsih di tahun 2018 menemukan hubungan yang signifikan antara sindrom premenopouse dengan tingkat stres. ${ }^{5}$ Stres sendiri bisa merangsang otak yang dapat mengganggu keseimbangan hormon. Jika hal ini terjadi secara terus menerus, maka akan menyebabkan semakin meningkatnya angka morbiditas dan mortalitas wanita. ${ }^{6}$ Mustopo menyebutkan bahwa stresor yang dirasakan oleh seorang wanita bisa berbeda-beda. Bagi mereka yang tidak menerima dengan realistis perubahan-perubahan yang dirasakan tersebut akan menimbulkan perasaan khawatir, takut, bahkan stres. Dengan datangnya menopause, seringkali wanita merasa dirinya tua, menilai dan berpikir dirinya loyo dan merasa tidak berarti lagi, merasa tersisihkan dan terabaikan dari kehidupan sosialnya. Hal ini akan dapat mengakibatkan stres pada wanita. ${ }^{7}$ Efikasi diri berperan sebagai satu mekanisme kognitif mengendalikan individu dalam menghadapi tekanan. Bandura menjelaskan bahwa efikasi diri akan meningkatkan kekebalan terhadap cemas, stres, depresi, dan dapat mengaktifkan perubahan-perubahan biokimia yang dapat mempengaruhi berbagai ancaman. ${ }^{8}$

Pittsburg menyebutkan sebanyak $80,9 \%$ wanita premenopause di dunia, tidak memiliki pengetahuan premenopause. ${ }^{8}$ Pengetahuan ini merupakan domain yang sangat penting untuk membentuk perilaku seseorang. Wanita yang memiliki pengetahuan terkait premenopause akan dapat memahami dan percaya diri dalam menangani masalah yang timbul saat terjadi perubahan. Sebaliknya apabila wanita tidak memiliki pengetahuan tentang premenopause, bisa berdampak pada kurangnya kesiapan dan kepercayaan diri menghadapi premenopause. Hal yang akhirnya bisa menyebabkan stres. ${ }^{9}$ Program kesehatan yang terkait dengan premenopause belum mendapat perhatian serius, misalnya, belum diberikan edukasi kesehatan tentang persiapan wanita dalam menghadapi premenopause yang dilaksanakan oleh pihak Puskesmas. Pelayanan kesehatan reproduksi wanita di Puskesmas, hingga saat ini terbatas pada pemeriksaan kehamilan ibu, pertolongan persalinan dan pelayanan keluarga berencana. Sementara, banyak wanita belum mengetahui tentang premenopause dan gejala-gejala yang menyertai, serta tidak mengetahui penyebab keluhan-keluhan yang mereka alami. ${ }^{10}$

Salah satu cara untuk menyiapkan wanita menghadapi masa premenopause ini adalah dengan cara mengubah kognitifnya melalui memberi edukasi menggunakan audio-visual dan booklet sebagai media. Hasil penelitian Khademol-hosseini pada tahun 2017 dan teori Glanz mengungkapkan bahwa edukasi dengan penerapan Health Belief Model, sangat efektif meningkatkan pengetahuan secara signifikan, dapat mengubah keyakinan kesehatan dan meningkatkan perilaku kesehatan. ${ }^{11,12}$ Health Belief Model sangat penting digunakan untuk mengembangkan kegiatan-kegiatan program pencegahan penyakit. Rasionalisasi terhadap Health Belief Model didasarkan atas perilaku masyarakat yang ingin mengubah perilaku kesehatan yang negatif, mencegah penyakit, dan menjaga kesehatan.

Hasil penelitian pendahuluan dilakukan pada 1 Januari 2019 di wilayah Kota Bandung 
melalui wawancara pada lima wanita usia 4051 tahun, menemukan bahwa empat wanita mengatakan stres menghadapi premenopause, stres karena menstruasi tidak teratur, kadang banyak sekali dan lama, cepat lelah, dan takut menjadi tua. Berdasarkan informasi dari salah satu petugas kesehatan, telah diketahui bahwa pendampingan pada wanita premenopause ini belum terlaksana. Diasumsikan bahwa adanya stres atau kekhawatiran wanita premenopause tersebut disebabkan belum cukupnya pemahaman terhadap premenopause. Penelitian ini bertujuan untuk mengetahui efektivitas media edukasi audio-visual dan booklet terhadap pengetahuan wanita mengenai premenopause, efikasi diri wanita, dan tingkat stres pada wanita premenopause.

\section{METODE}

Penelitian Quasi Experimental dengan pre and post test with control group design. Pengumpulan data dilakukan pada September -November 2019. Populasi penelitian adalah wanita premenopause dengan usia 40 tahun ke atas yang mengalami stres premenopause. Kota Bandung terdiri dari 30 kecamatan, dimana jumlah dan karakteristik dari wanita dengan pre-menopause di setiap kecamatan hampir sama. Lokasi penelitian ditentukan dengan teknik multistage random sampling. Hasil atas peng-undian pertama diperoleh wilayah Kecamatan Rancasari. Hasil atas pengundian yang kedua terpilih Kelurahan Cipamokolan. Hasil atas pengundian ketiga terpilih RW 06 sebagai kelompok intervensi, sedangkan daerah RW 05 sebagai kelompok kontrol.

Perhitungan besar sampel menggunakan rumus estimasi beda dua mean populasi. Sampel penelitian diambil dengan metode purposive sampling, di mana jumlah wanita premenopause yang memenuhi kriteria adalah 76 orang. Sebanyak 38 orang yang terpilih pada kelompok intervensi diberikan edukasi sebanyak satu minggu satu kali selama tiga minggu berturut-turut dengan menggunakan media audio-visual dan booklet, sedangkan 38 orang pada kelompok kontrol hanya diberikan booklet.

Pengukuran pengetahuan, efikasi diri dan stres dilakukan terhadap kelompok intervensi dan kelompok kontrol sebanyak dua kali, yaitu sebelum dan sesudah diberikan edukasi. Instrumen untuk mengetahui tingkat pengetahuan terlebih dahulu diujicobakan pada 20 responden. Hasil uji validitas dan realibilitas menunjukkan nilai 0,618. Efikasi diri diukur dengan menggunakan General Self-Efficacy Scale (GSE), dengan koefisien reliabilitasnya antara 0,76 dan $0,90 .{ }^{13}$ Tingkat stres diukur menggunakan kuesioner Perceived Stres Scale (PSS), dengan nilai koefisien cronbach alpha sebesar $0,85 .{ }^{14}$ Untuk PSS-10 dalam bahasa Indonesia, koefisien cronbach alpha sebesar 0,96. ${ }^{15}$ Alasan menggunakan GSE dan PSS karena pertanyaannya lebih aplikatif dan jumlah pertanyaan hanya terdiri dari 10 pertanyaan dirasa tidak memberatkan wanita premenopause dalam menjawabnya.

Uji normalitas yang digunakan adalah analisis Shapiro-Wilk. Mengingat salah satu kelompok data yang dibandingkan memiliki distribusi tidak normal, maka uji statistik untuk melihat perbedaan pengetahuan, efikasi diri, dan tingkat stres pre dan post-test pada kelompok intervensi dan kontrol digunakan uji Wilcoxon. Jika hasil uji normalitas salah satu kelompok data yang dibandingkan berdistribusi tidak normal, yaitu distribusi selisih skor pengetahuan, efikasi diri dan stres pada kelompok intervensi dan kontrol, (nilai $\mathrm{p} \leq 0,05)$, maka uji Mann Withney digunakan untuk mengetahui efektivitas media edukasi berupa audio-visual dan booklet terhadap pengetahuan, efikasi diri, dan stres wanita.

\section{HASIL}

Tabel 1 menunjukkan hasil bahwa kelompok intervensi, setelah diberikan edukasi dengan menggunakan media audio-visual dan booklet mempunyai rerata pengetahuan 6,09 poin lebih tinggi, efikasi diri 3,05 poin lebih tinggi, dan rerata tingkat stres terjadi penurunan lebih baik 1,23 poin dibandingkan kelompok kontrol. 
Tabel 1. Perbedaan Pengetahuan, Efikasi Diri, Stres Wanita Premenopause Sebelum dan Sesudah Intervensi pada Kelompok Intervensi dan Kontrol $(n=76)$

\begin{tabular}{llccccc}
\hline \multirow{2}{*}{ Variabel } & Kelompok & \multicolumn{2}{c}{$\begin{array}{c}\text { Sebelum } \\
\text { Rerata } \text { (Min-Maks) }\end{array}$} & SD & Rerata (Min-Mak: & SD \\
\hline \multirow{2}{*}{ Pengetahuan } & Intervensi & $59,99(20-80)$ & 16,3 & $80,33(60-100)$ & 10,2 & 0,001 \\
& Kontrol & $64,56(27-80)$ & 11,8 & $74,24(40-99)$ & 12 & 0,001 \\
\multirow{2}{*}{ Efikasi Diri } & Intervensi & $25,68(15-35)$ & 3,6 & $31,76(21-39)$ & 5 & 0,001 \\
& Kontrol & $27,18(22-34)$ & 2,7 & $28,71(21-37)$ & 3 & 0,016 \\
\multirow{2}{*}{ Stres } & Intervensi & $21,13(6-38)$ & 8,8 & $14,66(4-29)$ & 7,6 & 0,001 \\
& Kontrol & $18,66(8-27)$ & 5,2 & $15,89(5-24)$ & 4,9 & 0,012 \\
\hline
\end{tabular}

Tabel 2. Efektivitas Media Edukasi Audio-visual dan Booklet Terhadap Pengetahuan Wanita Premenopause

\begin{tabular}{lccc}
\hline \multicolumn{1}{c}{ Kelompok } & Rerata perubahan & $\mathbf{Z}$ & p-value \\
\hline Intervensi $(\mathrm{n}=38)$ & 20,34 & $-2,490$ & 0,013 \\
Kontrol $(\mathrm{n}=38)$ & 9,68 & & \\
\hline
\end{tabular}

Tabel 3. Efektivitas Media Edukasi Audio-visual dan Booklet Terhadap Efikasi Diri Wanita Premenopause

\begin{tabular}{lccc}
\multicolumn{1}{c}{ Kelompok } & Rerata perubahan & $\mathbf{Z}$ & p-value \\
\hline Intervensi $(\mathrm{n}=38)$ & 6,08 & $-4,15$ & 0,001 \\
Kontrol $(\mathrm{n}=38)$ & 1,39 & & \\
\hline
\end{tabular}

Tabel 4. Efektivitas Media Edukasi Audio-visual dan Booklet Terhadap Stres Wanita Premenopause

\begin{tabular}{lccc}
\multicolumn{1}{c}{ Kelompok } & Rerata perubahan & $\mathbf{Z}$ & p-value \\
\hline Intervensi $(\mathrm{n}=38)$ & 6,47 & $-5,76$ & 0,001 \\
Kontrol $(\mathrm{n}=38)$ & 2,76 & & \\
\hline
\end{tabular}

Tabel 2 menunjukkan nilai $\mathrm{p}=0,013$ yang artinya bahwa edukasi menggunakan media audio-visual dan booklet mengenai wanita premenopause dengan frekuensi selama 3 kali dapat meningkatkan pengetahuan wanita premenopause di Kota Bandung.

Pada Tabel 3 menunjukkan nilai $\mathrm{p}=0,001$, artinya bahwa edukasi menggunakan media audio-visual dan booklet mengenai wanita premenopause dengan frekuensi selama $3 \mathrm{kali}$ dapat meningkatkan efikasi diri dari wanita premenopause di Kota Bandung.

Tabel 4 menunjukkan hasil nilai $\mathrm{p}=0,001$, artinya edukasi menggunakan media audiovisual dan booklet mengenai premenopause selama 3 kali dapat mengurangi tingkat stres wanita premenopause di Kota Bandung.

\section{PEMBAHASAN}

Hasil analisis uji beda dua kelompok yang berpasangan, pada kelompok intervensi menunjukkan bahwa edukasi yang dilakukan dengan menggunakan media audio-visual dan booklet meningkatkan pengetahuan wanita premenopause. Hasil penelitian mendukung hasil penelitian yang dilakukan Silalahi pada tahun 2018 yang menemukan bahwa edukasi dengan audio-visual dan booklet efektif dalam meningkatkan perilaku melakukan skrining IVA. ${ }^{16}$ Hovland dan Weiss menjelaskan jika informasi disampaikan oleh seseorang yang ahli di bidangnya secara langsung dan dengan sukarela memberikan perhatian, maka pesan yang disampaikan akan lebih menarik dan mudah dipahami oleh responden. ${ }^{17}$

Hasil analisis dengan uji Mann Withney menunjukkan bahwa edukasi menggunakan media audio-visual dan booklet efektif untuk meningkatkan pengetahuan wanita mengenai premenopause. Peningkatan pengetahuan ini sejalan dengan pendapat Dale bahwa manusia memperoleh pengetahuan melalui indra yang dimilikinya, dimana semakin banyak indra yang digunakan untuk menerima informasi akan semakin banyak pula pengetahuan yang diperolehnya. Menurut cone of learning Dale, setelah masa dua minggu pengalaman belajar dengan mendengar, seseorang akan menyerap informasi yang didengar, dan sebanyak 20\% informasi akan tersimpan dalam memori, dan 
sebanyak $10 \%$ dengan membaca. ${ }^{18}$ Adapun menurut Notoatmodjo, bahwa pengetahuan yang diperoleh melalui indra penglihatan adalah sebesar $75 \%{ }^{9}$

Faktor yang mendukung pada penelitian ini adalah faktor wanita premenopause yang tidak bekerja, sebanyak $93,4 \%$ wanita premenopause tidak bekerja, sehingga banyak waktu luang yang dapat digunakan untuk membaca dan mempelajari isi booklet dan juga edukasi dilaksanakan satu kali seminggu sehingga akan ada waktu jeda untuk proses internalisasi dan juga mememori materi yang sudah dipelajari.

Hasil penelitian ini juga menunjukkan pentingnya edukasi kesehatan melalui audiovisual dan booklet sebagai sarana untuk memberikan pemahaman pada seseorang mengenai informasi yang bersifat positif sehingga akan diikuti perubahan perilaku yang positif. Audio-visual dan booklet berisi informasi tentang gejala premenopause dan tips cara mengatasi sendiri, seperti adanya perubahan pada tubuh yang diakibatkan oleh menurunnya hormon estrogen pada wanita premenopause. Hal tersebut akan diikuti oleh perubahan fisiologis dan psikologis. Ketika wanita paham akan perubahan yang terjadi dalam dirinya, mereka akan mampu merubah cara pandang dan perilakunya menjadi lebih baik.

Hasil analisis menggunakan uji beda dua kelompok berpasangan menunjukkan terdapat perbedaan yang bermakna pada kelompok control walaupun wanita premenopause hanya mendapatkan informasi dari booklet saja. Hal tersebut dapat menambah pengetahuan karena informasi yang terdapat dalam booklet cukup informatif. Materi booklet cukup menarik dan dibutuhkan karena didalamnya terdapat tips cara mengatasi perubahan fisiologis dan psikologis secara mandiri. Hal ini sesuai dengan ungkapan dari wanita premenopause pada saat post-test, yang menyatakan bahwa booklet sangat informatif, sederhana, mudah dimengerti dan mudah dibawa. Selain itu juga terdapat tips cara mengatasi sendiri yang sangat bermanfaat. Sebanyak 92,1\% wanita premenopause pada kelompok kontrol dengan tingkat pendidikan menengah ke atas. Kondisi ini menyebabkan mereka mampu untuk me- mahami booklet dengan lebih baik. Namun berdasarkan hasil peningkatan rerata skor pengetahuan, kelompok yang diberi edukasi menggunakan audio-visual dan booklet jauh lebih baik daripada kelompok yang hanya diberi edukasi menggunakan booklet saja. Hal ini dikarenakan kelompok yang hanya diberi edukasi dengan menggunakan booklet saja tidak mendapatkan informasi langsung dari tenaga kesehatan ataupun orang yang ahli di bidang premenopause.

Hasil analisis uji beda dua kelompok yang berpasangan, baik edukasi menggunakan media audio-visual dan booklet maupun edukasi menggunakan media booklet saja menunjukkan peningkatan efikasi diri wanita premenopause secara bermakna, akan tetapi efikasi diri wanita premenopause yang diberi edukasi menggunakan media audio-visual dan booklet adalah lebih baik. Edukasi kesehatan yang diberikan dengan menggunakan media audio-visual, diketahui dapat meningkatkan tingkat pengetahuan dan partisipasi wanita premenopause mengenai tanda dan gejala premenopause dan cara mengatasi gejalanya. Booklet dapat mempengaruhi pengetahuan, dibandingkan dengan media visual lain seperti poster. Media audio-visual dan booklet dapat digunakan untuk mendorong seseorang untuk mengetahui, mendalami dan mendapatkan pengertian yang baik, dan pendorong untuk melakukan sesuatu yang baru. Media audiovisual mampu memberikan stimulus pada pendengaran dan penglihatan.

Hasil penelitian ini telah menunjukkan bahwa edukasi dengan menggunakan media audio-visual dan booklet serta edukasi dengan media booklet saja, pengetahuan responden sama-sama meningkat, sedangkan edukasi dengan menggunakan audio-visual dan booklet pengetahuannya jauh lebih baik. Hasil penelitian tersebut sejalan dengan pendapat Notoatmodjo yaitu bahwa pengetahuan atau kognitif merupakan domain yang penting dalam membentuk tindakan seseorang. Wanita yang mengetahui tentang premenopause, akan mengerti dan percaya diri dalam melakukan penanganan pada saat terjadi perubahan. Namun orang yang memiliki pengetahuan yang kurang mengenai premenopause, berdampak pada kurangnya kesiapan dan kepercayaan 
diri menghadapi premenopause yang pada akhirnya akan menyebabkan stres. ${ }^{9}$

Hasil penelitian ini menunjukkan bahwa edukasi dengan melalui media audio-visual dan booklet efektif meningkatkan efikasi diri wanita premenopause. Hasil analisis dengan uji Mann Withney diperoleh nilai $\mathrm{p}<0,05$, artinya terdapat perbedaan yang signifikan antara efikasi diri wanita premenopause yang diberi edukasi menggunakan media audiovisual dan booklet dan edukasi yang hanya menggunakan booklet saja. Hasil penelitian ini juga sejalan dengan penelitian Kartono pada tahun 2014, yang menyatakan bahwa ada pengaruh antara edukasi kesehatan tentang penanganan kejang demam pada balita terhadap efikasi diri ibu. ${ }^{19}$ Edukasi kesehatan adalah praktik kesehatan yang dilakukan untuk merubah perilaku individu, kelompok, dan populasi yang lebih besar ke arah perilaku yang lebih baik, dan informasi yang benar akan memberikan stimulasi yang positif tentang perilaku hidup sehat. ${ }^{12,20}$ Edukasi kesehatan pada penelitian ini bermanfaat bagi wanita premenopause, hal ini karena wanita premenopause menjadi lebih paham tentang sindrom premenopause dan tips cara mengatasinya sendiri. Faktor yang mempengaruhi meningkatnya pengetahuan seperti pemberian informasi yang benar dan dari sumber lain yang tersedia. Selain itu ada faktor pendukung lain seperti media pembelajaran yang efektif, informasi kesehatan yang diberikan benar dengan komunikasi yang efektif. Dengan pengetahuan yang baik tentang premenopause akan meningkatkan kepercayaan diri atau efikasi diri wanita premenopause.

Edukasi dapat diberikan menggunakan beberapa media, seperti audio-visual dan booklet. Edukasi kesehatan menggunakan media audio-visual, dapat meningkatkan pengetahuan dan partisipasi wanita premenopause tentang tanda dan gejala premenopause dan cara mengatasinya. Booklet juga dapat mempengaruhi peningkatan pengetahuan, dibandingkan dengan media visual seperti poster. Media audio-visual dan booklet digunakan untuk mendorong keinginan seseorang untuk mengetahui kemudian mendalami dan akhirnya mendapatkan pengertian yang baik dan pendorong untuk melakukan sesuatu yang baru. Media audio-visual juga memberikan stimulus pada pendengaran dan penglihatan.

Seseorang yang telah mengetahui tentang premenopause akan mengerti dan percaya diri tentang penanganan pada saat terjadi perubahan. Efikasi diri menunjukkan pada keyakinan bahwa dirinya dapat melakukan tindakan yang dikehendaki oleh situasi tertentu dengan berhasil. Hal ini sejalan dengan pendapat Bandura, yang menyatakan bahwa keyakinan diri adalah pendapat atau keyakinan yang dimiliki seseorang mengenai kemampuannya dalam menampilkan suatu bentuk perilaku, dalam hal ini berhubungan dengan situasi yang dihadapi seseorang tersebut dan menempatkan sebagai elemen kognitif dalam pembelajaran. ${ }^{21}$

Hasil analisis uji Wilcoxon, baik edukasi menggunakan media audio-visual dan booklet maupun edukasi menggunakan booklet saja sama-sama dapat menurunkan tingkat stres wanita premenopause secara bermakna. Namun penurunan tingkat stres wanita premenopause yang diberi edukasi menggunakan media audio-visual dan booklet jauh lebih baik. Hal tersebut terjadi karena dalam penelitian ini edukasi dengan menggunakan media audio-visual dan booklet, serta edukasi dengan menggunakan media booklet saja, efikasi dirinya meningkat. Namun, edukasi yang menggunakan audio-visual dan booklet efikasi dirinya meningkat jauh lebih baik. Hasil penelitian ini sejalan dengan pendapat Bandura, bahwa efikasi diri akan meningkatkan kekebalan terhadap cemas, stres, depresi, dan mengaktifkan perubahan-perubahan biokimia sehingga mempengaruhi berbagai ancaman. ${ }^{8}$

Hasil dari analisis uji Mann Withney, didapatkan bahwa adanya perbedaan selisih skor stres yang bermakna antara edukasi menggunakan media audio-visual dan booklet dan edukasi dengan menggunakan booklet saja nilai $\mathrm{p}<0,05$. Pengetahuan merupakan segenap apa yang kita ketahui tentang suatu objek tertentu, termasuk didalamnya adalah ilmu. Pengetahuan dikumpulkan oleh ilmu dengan tujuan untuk menjawab permasalahan yang sehari-hari dihadapi oleh manusia. ${ }^{22}$ Menurut Clonninger, bahwa stres merupakan keadaan yang membuat tegang yang terjadi 
ketika seseorang mendapatkan masalah atau tantangan dan belum mempunyai jalan keluarnya, atau banyak pikiran yang mengganggu seseorang terhadap sesuatu yang akan dilakukannya. ${ }^{23}$ Gejala fisik yang dirasakan pada masa premenopause dapat memicu masalah psikis. ${ }^{6}$ Gejala fisik yang biasa muncul pada fase ini antara lain perasaan panas (hot flush), sulit tidur, dan siklus haid tidak teratur. Hal tersebut menyebabkan wanita premenopause menjadi stress, depresi, tidak konsentrasi bekerja, serta mudah tersinggung. Stres bukan hanya sakit secara emosional tapi bisa karena adanya kesalahan dalam pengetahuan, semakin banyak pengetahuan yang diketahui, maka kecemasan akan lebih mudah untuk diatasi. $^{24}$ Setiap wanita yang akan memasuki masa menopause harus memiliki pengetahuan yang memadai tentang menopause agar dapat menjalani masa tersebut dengan lebih tenang sehingga wanita tersebut tidak mengalami kecemasan yang merupakan stresor terhadap timbulnya stres pada wanita.

\section{KESIMPULAN}

Edukasi menggunakan media audiovisual dan booklet efektif untuk meningkatkan pengetahuan terkait premenopause dan efikasi diri wanita, serta efektif menurunkan tingkat stres pada wanita premenopause.

\section{SARAN}

Audio-visual dan atau booklet tentang premenopause dapat digunakan sebagai media edukasi sebagai upaya meningkatkan pengetahuan wanita premenopause tentang perubahan fisiologis dan psikologis yang terjadi selama masa premenopause, sehingga wanita premenopause menjadi percaya diri dan mampu menghadapi perubahan yang terjadi. Pada akhirnya wanita premenopause akan mampu mencegah dan mengatasi stres.

\section{UCAPAN TERIMA KASIH}

Penulis mengucapkan terimakasih kepada Politeknik Kesehatan Kemenkes Bandung yang telah membantu dalam memberikan bantuan dana, Kecamatan Rancasari dan Kelurahan Cipamokolan Kota Bandung yang telah mendukung penelitian, kader Posbindu, dan seluruh responden yang telah terlibat dalam penelitian.

\section{DAFTAR REFERENSI}

1. Dwi, S. A. Body mass index \& lama menopause berpengaruh terhadap kualitas hidup menopause. Jurnal Hospital Majapahit. 2017; 9(1): 28-41.

2. Harlow, et al. Executive summary of the stages of reproductive aging workshop +10 : addressing the unfinished agenda of staging reproductive aging. Menopause: The Journal of The North American Menopause Society. 2012; 19(4).

3. Nurdono, D.A. Gambaran sikap ibu terhadap masa premenopause pada ibu-ibu. Jurnal Online Psikologi. 2013; 1(2), http://ejournal.umm.ac.id/index. php/jop/ article/view/1640/1736.

4. Zul, M. A. R., Budiarti, A., Putri, E.C. Analisis faktor predisposisi dan kejadian premenopause terhadap tingkat stres pada ibu usia 40-55 tahun di Komunitas Ibu PKK RW 15 Kelurahan Pusat Jaya Surabaya. Jurnal Ilmiah Keperawatan. 2016; 11(1): $1057-$ 1058.

5. Anaqotul, F. H \& Suprihatingingsih, T. Hubungan syndrom premenopause dengan tingkat stres pada wanita usia 40-45 tahun. Jurnal Kesehatan Al-Irsyad (JKA). 2018; XI (1): 50-61.

6. Proverawati, A. \& Sulistyawati, E. Menopause dan sindrom premenopause. Yogyakarta: Muha Medika; 2010.

7. Sriwaty, I. \& Nuryoto, S. Pengaruh psikoedukasi menopause dan relaksasi untuk menurunkan kecemasan wanita pemenopause. Jurnal Humanitas. 2015; 12(1): 29-38.

8. Wulandari, S. \& Aliza, M. R. Efikasi diri dan stres akademik pada siswa sekolah menengah atas program akselerasi. Jurnal Psikologika. 2014; 19(2): 146-155.

9. Notoatmodjo, S. Ilmu perilaku kesehatan. Jakarta: Rineka Cipta; 2014.

10. Maria. Pengaruh edukasi terhadap pengetahuan dan kecemasan pada wanita premenopause di Desa Jendi Kecamatan Selogiri Kabupaten Wonogiri. Tesis. Perpustakaan uns.ac.id; 2011.

11. Khademolhosseini F, Noroozi A, Tahmasebi R. The effect of health belief model-based education through telegram instant messaging services on pap smear performance. Asian Pac J Cancer Prev. 2017; 18(8):22212226. 
12. Glanz K, Rimer B.K, Viswanath K. Health behavior and health education. San Fransisco: Jossey-Bass A Wiley Imprint; 2009.

13. Schwarzer, R., \& Jerusalem, M. Generalized self-efficacy scale. In J. Weinman, S. Wright, \& M. Johnston, Measures in health psychology: A user's portfolio. Causal and control beliefs (pp. 35-37). Windsor, UK: NFERNELSON; 1995

14. Cohen S, Kamarck T, Mermelstein R. A global measure of perceived stres. J. Health and Social Behavior. 1983; 385-396.

15. Pin, T L. Hubungan kebiasaan berolahraga dengan tingkat stres pada mahasiswa fakultas kedokteran universitas sumatera utara tahun masuk 2008. [Skripsi]. Medan: Fakultas Kedokteran Universitas Sumatera Utara; 2010.

16. Silalahi, V., Lismidiati, W., Hakimi, M. Efektivitas audiovisual dan booklet sebagai media edukasi untuk meningkatkan perilaku skrining IVA. Jurnal MKMI. 2018; 14(3): 304-315.

17. Ramdhani, N. Formation and attitude change. London: Faculty of Psychology; 2008 .
18. Arsyad, A. Media pembelajaran. Jakarta: PT Raja Grafindo Persada; 2011.

19. Kartono, S., Nurhayati, Y., Wulandari, IS. Pengaruh pendidikan kesehatan tentang penanganan kejang demam balita terhadap selfefficacy ibu di Desa tempur Sari Tambak Boyo Matingan Ngawi. Stikes Kusuma Husada Surakarta; 2014.

20. Rosser JI, Njoroge B, Huchko MJ. Changing knowledge, attitudes, and behaviors regarding cervical cancer screening: The efects of an educational intervention in rural Kenya. Patient Educ Couns. 2015; 98(7):884-889.

21. Bandura. "Self-efficacy in changing societies". New York: Cambridge University press; 1995.

22. Kartika. Pengertian pengetahuan, ilmu dan ilmu pengetahuan. 2011; (http:// karti kanfisip08.artikelkesehatan.com diakses tanggal 26/12/15).

23. Safaria, T., \& Saputra, N.E. Manajemen emosi. Jakarta: Bumi Aksara; 2009.

24. Baziad, A. Menopause dan andropause. Jakarta: Yayasan Bina Pustaka; 2009. 